\title{
TURUN RANJANG MARRIAGE IN INTERDISCIPLINARY PERSPECTIVE: A Study on The Community of West Java and Lampung
}

\author{
A. Kumedi Ja'far', Gandhi Liyorba Indra², Linda Firdawaty ${ }^{3}$, Rohmadi $^{4}$ \\ 1,2,3 State Islamic University (UIN) Raden Intan Lampung, Indonesia \\ Jl. Letkol. Endro Suratmin Sukarame Bandar Lampung \\ E-mail:khumeidi.jafar@radenintan.ac.id, gandhiliyorba75@gmail.com, linda.firda@radenintan.ac,id \\ ${ }^{4}$ State Institue for Islamic Studies (IAIN) Bengkulu, Indonesia \\ Jl. Raden Fatah, Pagar Dewa, Bengkulu \\ E-mail: rohmadisonhadji@gmail.com
}

\begin{abstract}
Turun ranjang marriage is a tradition that shows a widower or widow who married their brother or sister-in-law. This tradition of turun ranjang marriage only occurs when one married couple passes away. However, the existence of turun ranjang marriage is still understood as only part of the implementation of local culture. This paper took the object of West Java and Lampung's society by focusing on how the position and practice of turun ranjang marriage, as well as several perspectives within it, including: Islamic law, psychological, sociological, and economic perspectives. This research is a field research using the observation method, the interview method, and the documentation method. The results showed that the tradition of turun ranjang marriage is valid as long as the terms and conditions of marriage are fulfilled, both in Islamic law and national legal system. When viewed from the wedding procession, the two regions have something in common, namely that it is carried out more simply, in contrast to the usual wedding procession. However, if seen from the motive for turun ranjang marriage, the Lampung area aims to maintain traditional honor and to continue the lineage, while in West Java it aims to maintain family inheritance. The results of this study also indicate that economic, psychological, and social perspectives are factors that influence people's understanding of practicing turun ranjang marriage in having a happy and lasting family.
\end{abstract}

Kata Kunci: marriage; tradition; turun ranjang; interdisciplinary; West Java; Lampung.

Abstract: Perkawinan turun ranjang merupakan sebuah tradisi yang menunjukkan seorang duda atau janda yang mengawini adik atau kakak iparnya. Tradisi perkawinan turun ranjang ini hanya terjadi apabila salah satu pasangan suami istri meninggal dunia. Namun demikian, keberadaan perkawinan turun ranjang masih dipahami hanya sebatas bagian dari implementasi budaya lokal setempat. Tulisan ini mengambil objek di daerah Jawa Barat dan Lampung dengan menfokuskan kepada bagaimana kedudukan dan praktek perkawinan turun ranjang, serta beberapa pandangan dibalik perkawinan turun ranjang, antara lain: pandangan hukum Islam, psikologis, sosiologis, dan ekonomi. Penelitian ini merupakan penelitian lapangan (field research) dengan menggunakan metode observasi, metode interview, dan metode dokumentasi. Hasil penelitian menunjukkan bahwa tradisi perkawinan turun ranjang adalah sah selama syarat dan rukun perkawinan terpenuhi, baik secara hukum Islam maupun perundang-undangan. Jika dilihat dari prosesi perkawinan, kedua daerah tersebut memiliki kesamaan yaitu dilakukan dengan lebih sederhana, berbeda dengan prosesi perkawinan biasa. Namun, jika dilihat dari motif dalam melangsungkan perkawinan turun ranjang, maka daerah Lampung bertujuan untuk menjaga kehormatan adat dan untuk meneruskan garis keturunan, sementara di Jawa barat bertujuan untuk mempertahankan harta warisan keluarga. Hasil penelitian ini juga menunjukkan bahwa pandangan ekonomi, psikologi, dan sosial merupakan faktor yang mempengaruhi pemahaman masyarakat dalam melangsungkan pernikahan turun ranjang dalam membentuk keluarga yang bahagia dan kekal.

Kata Kunci: perkawinan; tradisi; turun ranjang; interdispliner; Jawa Barat; Lampung. 


\section{Introduction}

Marriage is a gateway to a happy family. Marriage Act No. 1 of 1974 article 1 states that marriage is a physical and spiritual bond between a man and a woman as a spouse with the aim of having a happy and eternal family based on the Almighty God. According to the Islamic Law Compilation, marriage is a forceful contract and mitsâqan ghalîzhan to obey Allah's commands, and carry it out as an actual worship. ${ }^{2}$ The birth bond in marriage means that formally it is husband and wife, and the inner bond in marriage means that in the mind of the husband and wife concerned there is a genuine intention to live together as a couple. ${ }^{3}$

In the context of Indonesian society, marriage is understood as a sacred event which is a forceful bond that must be preserved until the end of time. The sacredness of a marriage can be noticed when carrying out a marriage procession which usually requires much both time and money. This is interpreted as a form of readiness in fostering a household, both physically and psychologically. Even in customary rules, a widow or widower only recognizes divorce due to death as a form of loyalty to husband or wife. Divorce due to death is a divorce caused by the death of a married couple. In this case, when a divorce incident occurs due to the death of a spouse, special provisions apply by conducting a traditional marriage in which a widower or widow can marry their brother or sister-in-law. This marriage is known as turun ranjang marriage.

According to Hadi Kusuma, turun ranjang marriage is intended to make a substitute wife can provide offspring in order to continue family relationships. If the wife who has died and has had offspring, then the child left by the mother can be cared for properly with great love by the substitute wife, and can maintain the kinship of the two parties who have been bound by the previous marital relationship. ${ }^{4}$

Anik Farida, Perempuan dalam Sistem Perkawinan dan Perceraian di Berbagai Komunitas Adat, (JakartaTimur: Balai Penelitian dan Pengembangan Agama Jakarta, 2007), p. 11.

2 Abdurrahman, Kompilasi Hukum Islam di Indonesia, (Jakarta: Akademika Pressindo, 1992), p. 114.

3 AbdulKadir Muhammad, Hukum Perdata Indonesia, (Bandung: PT. Citra Aditya Bakti, 1993), p. 74

${ }^{4}$ Hilman Hadi Kusuma, Hukum Perkawinan Adat, (Bandung:
West Javanese (Sundanese) know the term turun ranjang marriage, that is, if a wife passes away, a husband of late wife will be married off to the younger sister of the late wife. In line with Lampungnese, turun ranjang marriage is a customary rule that must be obeyed for a man whose wife died in order to remarry another woman he loves without any conditions. As for a widow, she must follow the rules of turun ranjang and naik ranjang marriage. Women (widows) whose husbands passed away must follow the custom of turun ranjang and naik ranjang marriage. This means that if a widow wants to remarry, she must be with her husband's family. If she is married to the husband's older brother, it is called naik ranjang marriage. In contrary, if she is married to the husband's younger brother, it is called turun ranjang marriage. This is because women do not carry traditional honor, in order to continue the lineage, the widow's marriage is only allowed to follow turun ranjang and naik ranjang tradition. ${ }^{5}$

In turun ranjang marriage, problems arise in which there is confusion over the roles of husband and wife. Previously, the wife was a sister-in-law and then turned into a wife to replace the role of the previous marriage. In general, there are at least four main factors of adjustment related to marital problems, namely: marriage, sexual, financial, and the partner's family adjustment. ${ }^{6}$ In particular, in a turun ranjang marriage, it will depend on the extent of the compatibility between the husband and wife and the families of both parties, especially the suitability in understanding the concept of the role of husband and wife in carrying out turun ranjang marriage.

Based on the problems above, this paper would like to reveal more about how the concept of turun ranjang marriage is discussed from various perspectives, and how the implementation and impact of turun ranjang marriage in West Java and Lampung society.

\footnotetext{
PT. Citra Aditya Bakti, 1990), p. 70.

${ }^{5}$ Fathu Sururi, "Mak Di Juk Siang Pada Masyarakat Adat Lampung Pepadun Megou Pak”, Jurnal Al- Hukama, vol. 06, no. 01 (Juni 2016), pp. 134-137.

${ }^{6}$ Menurut Hurlock, Muhammad Iqbal, Psikologi Pernikahan; Menyelami Rahasia Pernikahan, (Jakarta: Gema Insani, 2018), p. 59.
} 


\section{Method}

This is field research conducted in West Java and Lampung related to turun ranjang marriage supported by library research. By using a descriptive-qualitative approach, this research aims to obtain an objective, accurate, and systematic description of the problems that exist in the research object. In order to collect data, several methods are used, namely, observation, interview, and documentation.

\section{Marriage in Islamic Perspective}

Marriage in Arabic is known as al-nikâh,? which means al-wath'u, al-dammu wa al-tadâkhûl, or al-dammu wa al-jam'u which means intercourse, gather, and contract. ${ }^{8}$ In some figh literatures, there are two terms, namely nikah and zawaj. 9 Those words can be used in a daily converstion and be written in the Quran and hadith of Prophet Muhammad. In the meaning of majaz, marriage means a contract, where the contract is the reason for allowing sexual intercourse. ${ }^{10}$ Marriage is a contract, hence marriage is defined as a forceful contract or mitsâqan ghalîzhan (ميثاقا غليظا) to fulfill Allah's commands and to carry them out as a worship. ${ }^{11}$

Furthermore, regarding the definition of marriage, several opinions can be stated as follows:

a. According to Sayuti Thalib, marriage is a holy, strong, and firm agreement to live together legally between a man and a woman in order to have an eternal, courteous, loving, loving, peaceful, and happy family. ${ }^{12}$

b. According to Hazairin, marriage is a sexual relationship, so there is no marriage (nikah) when there is no sexual relationship, for

\footnotetext{
7 Mahmud Yunus, Kamus Arab Indonesia, (Jakarta: Yayasan Penyelenggara Penterjemah/Pentafsiran Al-Qur'an, 1973), p. 468.

8 Amiur Nuruddin dan Azhar: Akmal Tarigan, Hukum Perdata Islam di Indonesia: Studi Kritis Perkembangan Hukum Islam dan Fikih, UU No. 1/1974 sampai KHI, (Jakarta: Prenada Media,2004), p. 38.

${ }_{9}$ Amir Syarifuddin, Hukum Perkawinan Islam di Indonesia; Antara Fiqh Munakat dan Undang-undang Perkawinan, (Jakarta: Kencana, 2006), p. 35.

${ }^{10}$ Abdurrahman Al-Jaziri, Fiqh ala Al-Madzahib Al-Arba'ah, (t.t: Dar al-Fikr, t.th), Juz. IV, p. 2.

${ }^{11}$ See Article 2 of Islamic Law Compilation.

${ }_{12}$ Moh. Idris Ramulyo, Hukum Perkawinan Islam, (Jakarta: BumiAksara, 2004), p. 2.
}

example, if there is no sexual relationship between couples, there is no need for a waiting period (iddah) to remarry the ex-wife to a another man. ${ }^{13}$

c. According to Mahmud Yunus, marriage (nikah) is a sexual relationship (intercourse), where he based his opinions on the hadith of the Prophet Muhammad namely Allah cursed people who marry (intercourse) with their hands. ${ }^{14}$

d. According to Ibrahim Husen, marriage (nikah) means that the lawful contract which allows sexual relations between man and woman. ${ }^{15}$

e. According to Imam Syafi'i, marriage is a contract by which sexual relations between man and woman are lawful, while according to the meaning of majazi (mathaporic) marriage means sexual relations. ${ }^{16}$

The laws of marriage are: Firstly, Compulsory, which is mandatory marriage for people who are able to increase piety, besides, marriage is also mandatory for people who are able to protect their souls and to save them from unlawful activities. This obligation will not be fulfilled unless getting married. Secondly, Haram, which is a forbidden marriage for people who know that they are not able to carry out a household both giving a living, clothes, shelter, etc., and doing sexual intercourse. Thirdly, Sunna, which is a marriage for people who are capable but are still able to control themselves (their desires) from unlawful acts. In this case, marriage is better than celibacy as celibacy is not recommended in Islam. Fourthly, Mubah, which is marriage for people who are not prevented from getting married and the urge to marry has not endangered him either, so he is not obliged to marry and it is not haram either.

The terms and conditions of marriage are firstly, husband, the conditions include: not the mahram of the prospective wife, not forced and voluntarily, the person (husband) is clear, not in

13 Hazairin, Hukum Kekeluargaan Nasional Indonesia, (Jakarta: Tintamas, 1964), p. 61.

${ }^{14}$ Baca kembali Mahmud Yunus, Hukum Perkawinan dalam Islam, (Jakarta: Al-Hidayah, 1964), p. 75.

15 Ibrahim Hosen, Figh Perbandingan, (Jakarta: Yayasan Al-lhya, 1971), p. 65.

${ }^{16}$ Moh. Idris Ramulyo, Hukum Perkawinan Islam..., p. 2. 
ihram condition. Secondly, the wife, the conditions include: there is no hindrance in syara', namely not being married, not in a mahram, and not in iddah condition, independent, on her own accord, the person (wife) is real, a Muslim, and is not currently practicing ihram. Thirdly, the guardian, the conditions include: male, baligh, rational, fair, able to see and hear well, of their own accord (not being forced), and not doing ihram. Fourthly, the witness, the conditions include: male, baligh, rational, not forced, fair, able to see and hear, not doing ihram, and understand the language used in the consent of Kabul. Fifthly, shigat (ijabkabul), the conditions include: sighat must be in an understandable language for people who carry out the contract, contract recipients, and witnesses. It also must be clear and complete, as well as continuous and consistent.

The objectives of marriage are getting and carrying on offspring, fulfilling human needs in lust, and giving love. Marriage aims to fulfill religious order, to protect oneself from crime and damage, to foster responsibility for accepting rights and obligations and obtaining lawful assets in order to make a peaceful society based on love and affection. ${ }^{17}$ Furthermore, marriage also aims to make a (holy) agreement between a man and a woman who have civil aspects, namely volunteerism, the agreement of both parties and freedom of choice..$^{18}$ The purpose of marriage in Islam is not only to fulfill the physical and spiritual needs of humans, but also to have a family, to nurture children, to continue offspring, and to prevent adultery in order to create peace and tranquility for the soul, family, and society. ${ }^{19}$

The fundamental principles of marriage can be seen from the juridical view (Marriage Act No.1 of 1974), namely: voluntary, monogamy, improving the status of women, complicating divorce, and maturity of the prospective groom/bride, family participation principles and registered legally to the government. ${ }^{20}$ The marriage principles are mawaddah wa rahmah

${ }^{17}$ Zakiyah Darajat dkk, Ilmu Fikih, (Jakarta: Depag RI, 1985), Jilid 3, p. 64.

${ }_{18}$ Tihami dan Sohari Sahrani, Fikih Munakat Kajian Fikih Nikah Lengkap, (Jakarta: Rajawali Press, 2013), p. 21

${ }^{19}$ Mohd. Idris Ramulyo, Hukum Perkawinan Islam..., p. 27

${ }^{20}$ Ahyuni Yunus, Hukum Perkawinan dan Isbat Nikah, (Makassar: Humanities Genius, 2020), pp. 16-18. (loving each other), mu'âsyarah bi al-ma'rûf (having polite and civilized behaviour), musyawarah (having an effective discussion and communication), and musawah (completing and protecting each other). ${ }^{21}$

\section{Turun Ranjang Marriage}

Turun ranjang marriage means a widow/ widower marries ex-spouse's sister. It generally is practices by a widower who marries his sister in law (ex-spouse's sister) due to his late wife's will. ${ }^{22}$ It possibly happens if husband passes away, the wife marries her late husband's brother.

In the context of customary and tradition practices, turun ranjang marriage is when a husband passed away and his wife married his younger brother, it is known as ganti baju or beripar turun marriage. However, if she married his older brother, it is known as saling bertingkat or beripar naik marriage. This tradition is also well knows as "ganti tikar" marriage, in which if the husband marries his late wife's older sister.

In terms of kinship marriages, turun ranjang marriage is known as the marriage of a widower or widow, in which he remains silent in the family of his late wife or her late husband, namely by marrying a young relative of the late wife or husband, and as if he were inherited by the late's brother wife or husband.

There are two types of turun ranjang marriage, namely: First, levirate marriage (replacing), which is a marriage between a widow and brother of her late husband, based on the prevailing customs in a society. Levirate is a marriage in which a woman marries her deceased husband's brother (due to death). This marriage in Islam is also allowed, for the sake of family integrity and security, especially those who already have children. This marriage is what we usually know as turun ranjang or naik ranjang marriage and applies to the patrilineal system..$^{23}$

${ }^{21}$ Musdah Mulia, "Prinsip-prinsip Perkawinan Islam, http:// mujahidahmuslimah.com/images/ document/prinsipperkawinan.pdf, accessed on October 17, 2019. See Khoiruddin Nasution, Hukum Perkawinan 1, (Yogyakarta: Academia + Tazzafa, 2004) p. 39.

${ }^{22}$ Sri jati dkk.,Buku Ajar Hukum Adat, (Jakarta: Kencana, 2018), p. 217.

${ }_{23}$ Jeanne Becher, Perempuan, Agama dan seksualitas, (Jakarta: Gunung Mulia, 2004), p. 14. 
Levirate is practiced by a widow. She does not return to her family after her husband passed away instead she marries her late husband's brother. ${ }^{24}$ It is not an obligatory but aims to keep the inheritance for the family and to have offsprings. ${ }^{25}$

It is also known as the marriage between a widow and her late husband's brother. It occurs due to an assumption that a wife has been bought by the husband with amount of money when to get married. It is still being practiced by Bataknese as Pareakhon, Javanese as Karang Wolu, Palembangnese as ganti tikar, Bengkulunese as kawinanggon. ${ }^{26}$

Second, Sororate marriage, which is a marriage between a widower and his late wife's sister. It is also known as anjutan, which means if a wife passed away, her husband would be allowed to marry her sister on behalf of her will. In customary perspectives, it is practice without having to dowry as the continuation of the previous marriage. In Central Java it is known as ngarangwulu, in Minangkabau as baganti laplak and in Pasemah as tungkat. ${ }^{27}$

Sororate marriage is an traditional marriage that determines whether a widower can or is encouraged to marry his wife's dead sibling or sibling's child. It is found in many Muju communities in Irian Jaya. People are familiar with the dowry payment system in installments. A husband is still obliged to pay off his dowry when his wife dies. After the debt was paid off, he was still required to marry his late wife's sister. If he takes another woman as his new wife, his ex-wife's family will be offended because they feel forgotten. This is also considered to be against adat law, and therefore the man who does it must pay a fine. In addition, the kinship between them will also be severed..$^{28}$

${ }^{24}$ Departemen Pendidikan dan Kebudayaan, Adat Istiadat Daerah Bengkulu, (Bengkulu: Pusat Penelitian Sejarah dan budaya, 1978), p. 158.

${ }^{25}$ Sri Warjiyati, Hukum Adat, (Yogyakarta: Deepublish, 2020), p. 94.

${ }^{26}$ Actor Primadona dan Mulati "Keabsahan Perkawinan Sedarah Masyarakat Adat Batak Toba Menurut Hukum Adat”, Jurnal Hukum Adigama, (2019), p. 15.

${ }_{27}$ P.N.H Simanjuntak, Hukum Perdata Indonesia, (Jakarta: Kencana, 2017), p. 110.

${ }^{28}$ Ina E. Slamet, Kehidupan Suku-Suku Irian Barat, (Jakarta: Jajasan Universitas Rakjat, 1963), p. 39.

\section{The Reasons of Turun Ranjang Marriage}

According to the customs and habits in the community, marriage is carried out for various reasons, to keep taking care of the family members left by the late wife, so that kinship between the two parties is maintained, in order to get offspring, and to maintain the relationship between the child and the stepmother, because it is considered better than the other stepmother.

For Lampungnese, turun ranjang marriage is a marriage caused by a dead wife, so the husband remarries his late wife's older or younger sister. There are several reasons for the occurrence of this marriage, for instance the substitute wife can provide offspring for the successor of the family, and if she already has offspring so that child can be properly cared for and looked after. ${ }^{29}$

According to interviews with one of the traditional leaders in the Mataram llir village, Gaya Baru explained that the reasons for turun ranjang marriage in Lampung customary tribe as follows:

a. Bring back dead people

During the interviews conducted towards local traditional leaders, the meaning of bringing back dead people means replacing the position of a deceased person, in this case the spouse. People who have died will have their role replaced by the younger sibling, in this case including the position of being a wife or if they already have children, they must replace the position of motherhood.

Based on Lampung customary tribe not only the positions of the wife and mother will be replaced but also other positions or roles, including the customary title held by the deceased, it will automatically be transfered to the substitute sibling. Custom titles in the Lampung tribe are arduous to obtain. In the customary tribe, the title of pepadun is not simply attached as it is not obtained by lineage. To take the title, people have to carry out a traditional ceremony which costs much money. The traditional ceremony is called Cakak Pepadun. After going through a series

29 Interview with Arlis Kurniati, Resident of Talang Jawa Village, Tanjung Bintang District, Lampung Selatan Regency, August 5, 2020. 
of traditional ceremonies or cakak pepadun, a person can obtain social titles or status, including the titles of Suttan, Raja, Prince, and Dalom. If a person who has carried out the cakak pepadun ceremony dies, the title can be replaced by his younger brother.

b. Responsible for looking after the children of the deceased spouse

As a substitute for a late spouse, the wife/ husband has the aim of continuing the care of the children so that they can be more secure in life carried out by close relatives who are still related by blood. Therefore the children will be calmer and more comfortable.

c. Keep the legacy of the deceased

In addition to being a substitute in child care, the role of the substitute is to safeguard the assets or legacy of the deceased so that it can be used properly.

d. Maintain the kinship

Kinship, in this case, is the relationship between two big families. Due to this marriage, the relationship will continue. ${ }^{30}$

In general, Lampungnese understand marriage as a strong and sacred bond, so divorce is an action that must be avoided. Divorce for the people of Lampung is understood as an action that can reduce dignity. Therefore, by getting doing turun ranjang marriage, it will bring customary honor and continue the offspring.

As in West Java, the reason for someone to do a turun ranjang marriage is to re-undergo the kinship system by the two families from the previous marriage. This is due to the fact that the implementation of this marriage is carried out at the request of the family or the will of the deceased wife to marry her sister. In addition, it is also carried out to maintain affection and the integrity of the family and children as well as to protect the family inheritance.

On the other hand, turun ranjang marriage has implications for the adjustment factors that occur in the couple. Based on the results of the author's interview with Mrs. Fitrotussa'adah, she

${ }^{30}$ Interview with Paduka Irawan, Resident of Seputih District, Lampung Tengah Regency, August 07, 2020. explained that this marriage because of the request of the family (child) and the will of the husband or wife who died to marry their substitutes. In turun ranjang marriage, the role of the family is fairly big in the relationship between the couples. This means that the process of marriage adjustment for a couple of turun ranjang marriage will be easier than for couples who are not. ${ }^{31}$

Based on the results of the interview above, it clearly showed that the turun ranjang marriage did not come from the desire of the partner, but because of the reason of the child and requests from the family. The general reason of a person deciding to get married is when there is a feeling of mutual liking and an emotional connection that occurs to the partner. Each of the couple's families already knows each other. Therefore when the marriage occurs, the turun ranjang couple will have no difficulty in adapting back to the partner's family. This condition enables the turun ranjang couples in making adjustments to the family.

\section{Turun Ranjang Marriage in Different Perspectives}

\section{Turun Ranjang Marriage in Islamic Law Perspective}

The legal position of turun ranjang marriage is valid as long as the terms and conditions of marriage are fulfilled, both in Islamic law and by national regulations. Regarding to turun ranjang marriage's iddah period, it is necessary to understand that there are two kinds of divorce between husband and wife. First, raj'i divorce, which is still possible for reconciliation. That is first and second divorce before the iddah period is over. Second, ba'in divorce, which is not possible for reconciliation, that is third divorce. The raj'i divorce enables the husband to wait for the completion of his first wife's iddah period, to be able to marry his wife's sister. However, ba'in divorce does enable husband to immediately marry his wife's sister, without having to wait for the end of his first wife's iddah period. These opinions are from Said bin Musayib, Hasân al-Basrî, Urwah bin Zubair, asShafî, AbûTsaur, Abû Ubaid, Ibnul Mundzîr, and several other scholars.

${ }^{31}$ Interview with Fitrotussa'adah, Resident of Cisolok District, Sukabumi Regency, West Java, August 15, 2020. 
An unlawful marriage is carried out when a husband marries siblings at the same time or is commonly known as adad. It is haram to marry two sisters at one time, both siblings and breastfeeding siblings. Fiqh does not explain turun ranjang marriage, it is only explained in Indonesia's custom. Ulama agree in accepting adat, namely customs in which there is no harm but benefits or the benefit is greater than the element of harm effects.

\section{Turun Ranjang Marriage in Indonesia Legal System Perspective}

Turun ranjang marriage according to national regulations does not contradict The Act No.1 of 1974 concerning Marriage, and turun ranjang marriage is a traditional marriage. The basis practice of customary law in Indonesia is contained in the 1945 Constitution of the Republic of Indonesia Article II Transitional Rules which reads "All existing state institutions are still functioning as long as they are to implement the provisions of the Constitution and have not yet been established according to this Constitution. The article above can be the legal basis of the turun ranjang marriage tradition. The practice of adat is sociologically obeyed by community members although it is not expressly stated in a regulation. Therefore, the legal status and position of this marriage is legal as long as the terms and conditions of marriage are fulfilled, both in Islamic law and by regulations.

Therefore, turun ranjang marriage can be enforced as long as there is a governing law. In addition, it also shows local wisdom as the identity of the nation, and the enactment of this marriage custom is to strengthen the unity in kinship and togetherness. ${ }^{32}$

\section{Turun Ranjang Marriage in Economic Law Perspective}

Marriage is a union of two people, different habits and cultures, so that in carrying it out there must be many adjustments, including understanding the economic situation. In undergoing marriage, one of the problems is the economy. For newly

32 Dominikus Rato, Hukum Adat di Indonesia; Suatu Pengantar, (Surabaya: Laksbang Justitia, 2014), p. 111-112. married couples, they must be able to adapt or accept economic conditions at the beginning of marriage. In turun ranjang marriage, it is not too difficult to understand each other's economic situation, because in previous kinship they already know each other's economic situation. ${ }^{33}$

In addition, turun ranjang marriage can also maintain wills related to the deceased's business or to continue the work of the deceased, so that the family's financial or economic business will return to stability. This is one of the goals of this marriage, because siblings tend to be more understanding and more loyal to their families than when they marry new people. The communication relationship between families in matters of financial management or inheritance left by the deceased will be easier because financial management is still in the hands of relatives.

\section{Turun Ranjang Marriage in Psychology Perspective}

Turun Ranjang marriage from psychology perspective is the ability to control the emotions. This emotional maturity is necessarily required for the marriage couple ${ }^{34}$ as it determines the permanence and harmony of a marital relationship. In a turun ranjang marriage, it is not difficult to find tolerance, respect, and assistance among partners. In addition, it is also carried out to maintain the psychology of the child from the previous marriage, a deep sense of loss will really shake the psyche of the children so that in order to treat the loss, it can be replaced with a sibling from the mother. ${ }^{35}$

Through the shifting care of the mother's sibling, the child will not feel uncomfortable or alienated from their mother's substitute figure because the substitute figure is not someone they just met. Children will also be more congenial, calm, and secure if the care is done by their own siblings. From the side of parents, especially mothers, as someone who replaces the role of their sibling in caring for children, psychologically there is a close

33 Nurul Chomaria, Cerdas Finansial ala Keluarga Muslim, (Jakarta: PT Elex Media Komputindo, 2015), p.45.

${ }^{34}$ Faizal Kurniawan, Keluarga dan Budaya dalam Tinjauan Sosiologis, (Jakarta: G4 Publishing, 2011), p.32.

35 Masganti Sit, Psikologi Perkembangan Anak Usia Dini Edisi Pertama, (Depok PT Kharisma Putra Utama, 2017), p.7. 
bond between them and their siblings' children, because they are still single so they will not be negligent and arbitrary in taking care and educating children from previous marriage.

\section{Turun Ranjang Marriage in Sociology Perspective}

As a social being, humans cannot be separated from others and the environment around them. In social life, marriage becomes one of the means which humans come together to plan, to prepare, and to celebrate wedding. Turun ranjang marriage is rare in society. It occurs because of certain things. There are some people who think that it is taboo or not commonly practiced in society, this happens because there are several factors that influence people's understanding of turun ranjang marriage, namely religious understanding, custom carried out by local communities, and individual factors.

From a sociological perspective, turun ranjang marriage will make married couple easier to adapt to their family and environment, because of the support from both families. In addition, it can also make couples understand each other's conditions and strength, so that it has a good impact in living a married life.

\section{The Practices of Turun Ranjang Marriage in Jawa Barat and Lampung}

\section{Turun Ranjang Marriage in Jawa Barat}

The traditional West Java wedding procession can generally be divided into three parts, namely the procession before the wedding, when the contract/akad, and the after the contract/akad. The processions before the West Java traditional wedding are Neundeun Omong, Ngalamar, Seserahan, Ngecangkeun Aisan, Ngaras, Siraman, Ngerik, and Ngeuyeuk Seureuh. Meanwhile, the processions during the contract are picking up and welcoming the prospective groom, performing the marriage contract, handing over the dowry, and Sungkeman. Then the procession after the contract, namely Sawer Pengantin, Nincak Endog (stepping on eggs), Meuleum harupat (burning the stick), opening the door, Huap lingkung, letting go of a pair of doves, and Numbas. ${ }^{36}$

\footnotetext{
${ }^{36}$ Interview with Fitrotussa'adah, Resident of Cisolok
}

In the implementation of turun ranjang marriage in West Java, it is particularly mutual to the implementation of ordinary marriage in general. Likewise in traditional ceremonies, there is not much difference between turun ranjang and general marriage. The implementation of this marriage in West Java can be performed either on a large or a small scale. It then depends on the ability and desire of the married couple. However, in general, turun ranjang marriage is carried out in a simple manner, that is, it is enough to hold a marriage contract and tasyakuran which is attended by traditional figure or kesepuhan in West Javanese terms. In the practice of this marriage, kesepuhan can act as a witness in the marriage and a figure who provides marriage advice. ${ }^{37}$

\section{Turun Ranjang Marriage in Lampung}

The practice of turun ranjang marriage in Lampung as follows:

a. Nyuwakh ghupekh or visit traditional leaders. Prior to marriage, the bride and groom are required to visit local traditional leaders with the aim of asking permission to carry out the turun ranjang marriage, this is also related to the transfer of title that will be carried out when the marriage has been performed. Customary leaders must be informed about this marriage because if the couples does not get permission, they will be subject to a customary fine (cakak lalang). Customary fine if they violate this rule is giving money and the heaviest punishement is to be removed from adat. For money, it is depending on the position, the higher the title the greater the fine. The lowest fine starts with a nominal value of Rp. 6,000.00 and this fine is then multiplied by the number 6 according to the higher level and title. After carrying out the marriage, the traditional leader will later inform the surrounding community that the title held by the deceased will be transferred to his/her substitute.

b. Ngeluwahke duwit dau which means giving money for adat. Ngeluwahke duwit dau is given

\footnotetext{
District, Sukabumi Regency, West Java, August 15, 2020.

37 Interview with Yandi Maryandi, Resident of Cibiru District, Bandung Regency, August 15, 2020.
} 
to the traditional leader as a turun ranjang requirement. The amount of money depends on the request of adat leader, it commonly starts from Rp 2.400,00 to Rp 2.400.000,00. It has absolutely been considered wisely by them according to the ability of the married couple. This money can be categorized as number 2 and 4.

c. Conducting a marriage contract in front of the leader in accordance with the Islamic law and before traditional leaders. This marriage contract is generally the same as any other marriage, which is in accordance with the Sharia or Islamic teachings.

d. Adat Ceremony of Begawi. In turun ranjang marriage, some people practise begawi or ceremony but some do not. It does not simply affect the adat ceremony as it is based on the couple's financial ability. ${ }^{38}$

\section{The Implications of Turun Ranjang Marriage for the Society of West Java and Lampung}

\section{The Implications of Turun Ranjang Marriage for West Java Society}

The positive impact of turun ranjang marriage for the people of West Java can maintain and adapt the relationship between families well, so that there is no awkwardness in interacting with extended families, and if the couple already has children in a previous marriage, the deceased's younger siblings will definitely consider their own children, so there is no worry in childcare issues.

Negative Impact for the younger siblings of the deceased spouse, because not all of them can accept the fact that to marry the husband of her late sibling, is she will undergo a forced marriage. There will be scorn from the surrounding community who consideres the marriage is a disgrace and ancient.

\section{The Implications of Turun Ranjang Marriage for Lampung Society}

The positive impact of turun ranjang marriage is that it continues to strengthen the relationship

${ }^{38}$ Interview with Ratu Siwati, Resident of Seputih Surabaya District, Mataram Ilir Lampung Tengah Regency, August 07, 2020. between two relatives or families that have been established as a result of the previous marriage. Then for the deceased who has a customary title, the customary title can be passed on to his/her younger siblings, in order to preserve the customary title. Furthermore, the deceased who has valuable inheritance and legacy can be properly preserved and does not turn to other parties, because they are still held by their own family and the children of the deceased can be guaranteed their life.

Meanwhile, the negative impact of this marriage is that it can lead to the notion that the marriage is a family disgrace, and of course it will become gossip and scorn among the surrounding community. People do not know much about this unusual marriage nowadays

\section{Conclusion}

According to the perspective of Islamic law, turun ranjang marriage is permissible and legal, as long as the terms and conditions of marriage are met, then according to a positive legal perspective, it is a traditional marriage that can be enforced as long as it does not conflict with applicable regulations. Based on economic law perspective, it can maintain business continuity and inheritance from previous marriages, so that they will not be transferred to other people. Furthermore, from a psychological perspective, it is practiced to keep the child's psychology from losing a mother/father. Meanwhile, the sociological perspective shows that it will enable the partners and families to adapt.

The practice of turun ranjan marriage and the traditional ceremony in West Java is not particularly different from the practice of ordinary marriage in general. It is just that from the point of view of the stages of implementation of this marriage, it is carried out more simply than an ordinary marriage, namely by presenting traditional or senior figures. This Kesepuhan can act as a witness and as a figure providing marriage advice. Likewise, the practice of this marriage in Lampung is by visiting traditional leaders or Nyuwakhghupekh with the aim of requesting permission to carry out a turun ranjang marriage, and also related to the transfer of traditional titles. 
The impact of turun ranjang marriage in West Java is that it is easy to adapt so that there is no awkwardness in interacting with extended families and a sense of affection for the deceased's child. Meanwhile, the impact of this marriage in Lampung is that it can strengthen the relationship between two relatives or families that have been established as a result of a previous marriage. This marriage can also preserve inheritance, legacy, and customary title.

\section{References}

Abdurrahman, Kompilasi Hukum Islam di Indonesia, Jakarta: Akademika Pressindo, 1992.

Becher, Jeanne, Perempuan, Agama dan seksualitas, Jakarta: Gunung Mulia, 2004.

Chomaria, Nurul, Cerdas Finansial ala Keluarga Muslim, Jakarta: PT Elex Media Komputindo, 2015.

Darajat, Zakiyah dkk, Ilmu Fikih, Jakarta: Depag RI, 1985, Jilid 3.

Departemen Pendidikan dan Kebudayaan, Adat Istiadat Daerah Bengkulu, Bengkulu: Pusat Penelitian Sejarah dan budaya, 1978.

Farida, Anik, Perempuan dalam Sistem Perkawinan dan Perceraian di Berbagai Komunitas Adat, JakartaTimur: Balai Penelitian dan Pengembangan Agama Jakarta, 2007.

Hazairin, Hukum Kekeluargaan Nasional Indonesia, Jakarta: Tintamas, 1964.

Hosen, Ibrahim, Figh Perbandingan, Jakarta: Yayasan Al-Ihya, 1971.

Iqbal, Muhammad, Psikologi Pernikahan; Menyelami Rahasia Pernikahan, Jakarta: Gema Insani, 2018.

Jati, Sri dkk, Buku Ajar Hukum Adat, Jakarta: Kencana, 2018.

Jaziri, Abdurrahman Al- Figh ala Al-Madzahib AlArba'ah, t.t: Dar al-Fikr, t.th, Juz. IV.

Kurniawan, Faizal, Keluarga dan Budaya dalam Tinjauan Sosiologis, Jakarta: G4 Publishing, 2011.

Kusuma, Hilman Hadi, Hukum Perkawinan Adat, Bandung: PT. Citra Aditya Bakti, 1990.
Muhammad, Abdul Kadir, Hukum Perdata Indonesia, Bandung: PT. Citra Aditya Bakti, 1993.

Mulia, Musdah, "Prinsip-prinsip Perkawinan Islam, http://mujahidahmuslimah.com/images/ document/prinsipperkawinan.pdf, accessed on Oktober 17, 2019.

Nasution, Khoiruddin, Hukum Perkawinan 1, Yogyakarta: Academia + Tazzafa, 2004.

Nuruddin, Amiur dan Azhar, Akmal Tarigan, Hukum Perdata Islam di Indonesia: Studi Kritis Perkembangan Hukum Islam dan Fikih, UU No. 1/1974 sampai KHI, Jakarta: Prenada Media, 2004.

Primadona, Actor dan Mulati "Keabsahan Perkawinan Sedarah Masyarakat Adat Batak Toba Menurut Hukum Adat", Jurnal Hukum Adigama, 2019.

Ramulyo, Mohd. Idris, Hukum Perkawinan Islam, Jakarta: BumiAksara, 2004.

Rato, Dominikus, Hukum Adat di Indonesia; Suatu Pengantar, Surabaya: Laksbang Justitia, 2014.

Simanjuntak, P.N.H, Hukum Perdata Indonesia, Jakarta: Kencana, 2017.

Sit, Masganti, Psikologi Perkembangan Anak Usia Dini Edisi Pertama, Depok PT Kharisma Putra Utama, 2017.

Slamet, Ina E., Kehidupan Suku-Suku Irian Barat, Jakarta: Jajasan Universitas Rakjat, 1963.

Sururi, Fathu, "Mak Di Juk Siang Pada Masyarakat Adat Lampung Pepadun Megou Pak," Jurnal Al- Hukama, vol. 06, no. 01, Juni 2016.

Syarifuddin, Amir, Hukum Perkawinan Islam di Indonesia; Antara Fiqh Munakat dan Undangundang Perkawinan, Jakarta: Kencana, 2006.

Warjiyati, Sri, Hukum Adat, Yogyakarta: Deepublish, 2020.

Yunus, Ahyuni, Hukum Perkawinan dan Isbat Nikah, Makassar: Humanities Genius, 2020.

Yunus, Mahmud, Hukum Perkawinan dalam Islam, Jakarta: Al-Hidayah, 1964.

, Kamus Arab Indonesia, Jakarta: Yayasan Penyelenggara Penterjemah/Pentafsiran AlQur'an, 1973. 